\title{
Characterization of caseous lymphadenitis in caprine animals slaughtered in a semi-arid region of Brazil
}

\section{Caracterização da linfadenite caseosa em caprinos abatidos no semiárido brasileiro}

\author{
Nathanael Natércio da Costa Barnabé ${ }^{1}$; José Dêvede da Silva ${ }^{1}$; Maira Porto \\ Viana $^{1}$; Newcelia Paiva Barreto²; Évyla Layssa Gonçalves Andrade²; Pedro Jorge \\ Álvares de Faria ${ }^{3}$; Albério Antônio de Barros Gomes ${ }^{4}$; Severino Silvano dos Santos \\ Higino $^{4}$; Sérgio Santos de Azevedo ${ }^{4}$ Clebert José Alves ${ }^{*}$
}

\begin{abstract}
In the Northeast of Brazil, goat breeding plays an important socioeconomic and strategic role in coexistence within the semi-arid region. The rural nature of the species and adaptations that are appropriate for the climate are some of the characteristics that favor the Northeast as the largest national producer of goats ( $93 \%$ of the national herd). In spite of this, sanitary deficiencies facilitate the appearance and diffusion of pathogenic agents that compromise the productivity, e.g., Corynebacterium pseudotuberculosis, which are widespread in the national herd and cause damages in the industry. The objective of this study was to characterize caseous lymphadenitis (CL) in lamb cuttings at semi-arid abattoirs. The research was carried out between March and August 2017 at the Municipal Abattoir of Patos, State of Paraíba, Brazil, where the caprines from this region are slaughtered. We studied 304 animals with no defined racial pattern, of both the sexes, characterized according to their age group as evidenced by their teeth, submitted to ante- and post-mortem examinations with microbiological confirmation. Cheek material was processed for diagnostic confirmation, using the techniques of isolation and microbiological identification (gold standard). The bacteriological examination confirmed the presence of the agent in $21.38 \%$ of the animals, in which $13.16 \%$ were females and $8.22 \%$ were males. Of those affected, $11.51 \%$ had the clinical form of the disease, while $9.87 \%$ had the subclinical form and $1.31 \%$ had both the clinical form as well as the internal impairment. The precrural $(25.71 \%)$, mammary $(11.43 \%)$, and prescapular $(11.43 \%)$ lymph nodes were the most affected. Internally, the most affected were the liver (63.33\%), lung (13.33\%), and medium mediastinal lymph nodes $(10 \%)$. The presence of skin lesion/scars (Odds ratio $=2.394,95 \% \mathrm{CI}=1.371-4.182, p=0.003)$ and sex (females) (Odds ratio $=1.845,95 \% \mathrm{CI}=1.053-3.232, p=0.044)$ were found to be risk factors. CL is present in goats from the intermediate geographical region of Patos, reinforcing the need for control measures, with attention to the inspection of animals in the slaughter line.
\end{abstract}

Keywords: Northeast. Goat breeding. Slaughterhouse. Corynebacterium pseudotuberculosis. Injury.

\footnotetext{
1 Discentes, Curso de Doutorado, Programa de Pós-Graduação em Ciência e Saúde Animal, Universidade Federal de Campina Grande, UFCG, Patos, PB, Brasil. E-mail: nathannaterciomv@gmail.com; dvd.12@hotmail.com; mairaporto.veterinaria@ gmail.com

2 Mestres, Programa de Pós-Graduação em Ciência Animal, UFCG, Patos, PB, Brasil. E-mail: newcelia.barreto@bol.com.br; evylalayssa@hotmail.com

3 Bacharel em Medicina Veterinária, UFCG, Patos, PB, Brasil. E-mail: alvaresfaria@gmail.com

4 Profs., Programa de Pós-Graduação em Ciência e Saúde Animal, UFCG, Patos, PB, Brasil. E-mail: alberiogomes@bol.com.br; higinosss@gmail.com; sergio@vps.fmvz.usp.br; clebertja@uol.com.br

* Author for correspondence
} 


\section{Resumo}

No Nordeste do Brasil a caprinocultura desempenha importante função socioeconômica e estratégica na convivência em região semiárida. A boa adaptação ao clima somado a rusticidade da espécie são algumas das caraterísticas que favorecem o Nordeste como maior produtor nacional ( $93 \%$ do efetivo). Apesar dessa condição, deficiências sanitárias proporcionam surgimento e difusão de agentes patogênicos que comprometem a produtividade, destacando-se o Corynebacterium pseudotuberculosis, difundido no rebanho nacional e que gera prejuízos à atividade. O objetivo deste estudo foi caracterizar a Linfadenite Caseosa (LC) na caprinocultura de corte em abatedouro do semiárido. Desenvolveu-se a pesquisa entre março e agosto 2017 no Abatedouro Municipal de Patos, Estado da Paraíba, Brasil, onde ocorre abate de caprídeos provenientes desta região geográfica intermediária. Foram estudados 304 animais sem padrão racial definido, ambos os sexos, caracterizados conforme faixa etária evidenciada pelos dentes, submetidos a exames ante e post mortem com confirmação microbiológica. Processou-se material caseoso dos doentes; para confirmação de diagnóstico se empregou a técnica de isolamento e identificação microbiológica (padrão ouro). O exame bacteriológico confirmou presença do agente em $21.38 \%$ dos animais. As fêmeas representaram $13.16 \%$ dos doentes, enquanto os machos, $8.22 \%$. Dos acometidos, $11.51 \%$ apresentaram a forma clínica, enquanto $9.87 \%$ a subclínica; $1.31 \%$ tiveram simultaneamente forma clínica e comprometimento interno. Os linfonodos pré-crurais $25.71 \%$, mamários $11.43 \%$ e préescapulares $11.43 \%$ foram mais afetados; internamente, fígado $63.33 \%$, pulmão $13.33 \%$ e linfonodo do mediastino médio $10 \%$. Comprovou-se como fatores de risco a presença de lesão/cicatriz cutânea (Odds ratio $=2.394 ;$ IC $95 \%=1.371-4.182 ; p=0.003)$ e o sexo (fêmea) $($ Odds ratio $=1.845 ;$ IC 95\% $=1.053$ - 3.232; $p=0.044)$. A LC se encontra presente em caprinos da região geográfica intermediária de Patos, reforçando a necessidade de medidas de controle, com atenção à inspeção de animais na linha abate.

Palavras-chave: Nordeste. Caprinocultura. Abatedouro. Corynebacterium pseudotuberculosis. Lesões.

\section{Introduction}

Goat farming is an important activity in the Brazilian Northeast, not only from an economic point of view, but also as a coexistence strategy in the semi-arid region. According to Farias et al. (2014), the species Capra hircus easily adapts to the climatic conditions of this area, a characteristic that makes the Northeast the largest producer in Brazil, with 7.660.715 goats, which is approximately 93\% of the national herd (8.254.561) (IBGE, 2018). Although these are impressive numbers, production is considered low due to factors such as long periods of droughts, lack of technical information, farmers with low educational levels, and sanitary and hygienic management problems that lead to the emergence, maintenance, and dissemination of infectious diseases, ultimately decreasing the meat, milk, or leather quality (GUILHERME et al., 2017; RODRIGUES et al., 2016; TEIXEIRA et al., 2015).

One of these contagious infectious diseases is caseous lymphadenitis (CL), which is caused by the aerobic non-sporulating Gram-positive bacterium Corynebacterium pseudotuberculosis, a facultative intracellular macrophage parasite (GUILHERME et al., 2017; OREIBY, 2015; RODRIGUES et al., 2016; TEIXEIRA et al., 2015; WINDSOR; BUSH, 2016). This bacterium releases an exotoxin known as phospholipase D (PLD), which is the main virulence factor that increases vascular permeability and causes inflammation with subsequent necrosis (WINDSOR, 2014).

Fistulated granuloma is the main source of transmission. Infection may occur through direct contact with purulent discharge, consumption of contaminated water or food, inhalation of aerosols, and even through fomites (ALVES et al., 2007; VESCHI et al., 2015). It is a chronic pyogenic infectious disease, which can be either clinical (superficial lymph nodes hypertrophy and/or extralymph-node abscesses) or subclinical (involvement of internal organs and/or lymph nodes). Additionally, it may present clinical signs and internal lesions simultaneously (FACCIOLI-MARTINS et al., 


\section{4; OREIBY, 2015).}

Its diagnosis has been the subject of intense research for more than a century. There is no single test to identify all cases, or even different stages. Microbiological isolation is considered the gold standard for clinical cases. The enzymelinked immunosorbent assay (ELISA) serological test is based on the detection of immunoglobulin $\mathrm{G}(\mathrm{IgG})$ as a marker of humoral activity, with the cell-mediated response based on the quantification of interferon- $\gamma$ (IFN- $\gamma)$. The molecular test is based on a polymerase chain reaction (PCR) with genetic material detection (OREIBY, 2015) by the $16 \mathrm{~S}$ rRNA, rpoB, pld and 12S rRNA gene markers (PACHECO et al., 2007).

The disease causes an economic loss due to treatment costs, decreased production, condemned carcasses and viscera, and skin devaluation (SOUZA et al., 2011). It is considered a significant obstacle for goat breeding around the world, with some countries having a prevalence rate of up to 80\% (VESCHI, 2011). In Brazil, it is estimated that most herds are infected, the clinical prevalence of which can vary from 5\% to 50\% (ANDRADE et al., 2012; PEREIRA et al., 2017; RIZZO et al., 2017; SOUZA et al., 2011; SOUZA et al., 2014). In addition to economic concerns, disease control is important for preserving human health. According to Faccioli-Martins et al. (2014), CL is an emerging zoonosis transmitted through contact with infected animals and contaminated dairy products.

Therefore, it is necessary to update the disease's epidemiological indicators, seeking new information to improve combat strategies. Thus, the objective of this research was to characterize CL in goats sent to a slaughterhouse in a semi-arid region, through ante- and post-mortem examinations with microbiological confirmation.

\section{Materials and Methods}

This research was conducted from March to August 2017 at Patos Municipal Slaughterhouse (latitude $7^{\circ} 00^{\prime} 19^{\prime \prime} \mathrm{S}$ and longitude $37^{\circ} 16^{\prime} 48^{\prime \prime} \mathrm{W}$ ), Paraíba, Brazil, where goats from this intermediate geographical region are slaughtered. According to data from the Animal Transit Form (GTA), provided by the Agriculture and Fishery Development Secretariat (SEDAP - PB) in 2017, 3.662 goats were slaughtered, a monthly average of 305 . In the study period, 1.269 were slaughtered, an average of 212/ month.

Sampling was calculated based on the minimum sample number $(N)$, using the simple random sampling formula, an expected prevalence of $50 \%$ for maximization, a $95 \%$ confidence interval, and a 6\% sampling error (THRUSFIELD, 2007). According to the formula, the minimum number is 267, however, 304 mixed-breed animals of both sexes and varying ages were used. The animals were stratified into five age groups (less than 12, 12-24, 24-36, 36-48, and more than 48 months), which were established by the adapted chronology of dental development proposed by Frandson et al. (2011).

The animals underwent ante-mortem examinations in the slaughterhouse, including the inspection and palpation of superficial parotid, submandibular, prescapular, precrural, popliteal, and mammary lymph nodes. Animals that showed clinical signs compatible with CL were included in the study and identified with a permanent earring in the right ear. Fistulated abscess scars and identification markings (an ear cut, for example) were registered.

Carcasses and viscera (heart, lung, esophagus, liver, spleen, rumen, reticulum, omasum, abomasum, and intestines) were identified with 912 acetate labels $(45 \times 30 \mathrm{~mm})$ and white adhesive paper $\left(25 \times 15 \mathrm{~mm}\right.$, Artgraf Etiquetas $\left.{ }^{\odot}\right)$ with the corresponding number secured with adhesive tape $\left(19 \mathrm{~mm}\right.$, Adelbras $\left.^{\odot}\right)$ and tied with a red string for easier localization. The veterinarian responsible for the slaughterhouse conducted the post-mortem examinations, to search for lesions that could indicate the presence of the disease. 
Granuloma samples were stored in zipped plastic bags (N9 $200 \times 280 \mathrm{~mm}$, Talge $\left.{ }^{\odot}\right)$, duly identified, and sent refrigerated to the Laboratory of Communicable Diseases (LDT), Health, and Rural Technology Center (CSTR) at the Federal University of Campina Grande (UFCG), Patos Campus, where they were immediately processed.

Microbiological culture, the gold standard diagnosis (OREIBY, 2015), was used. This included a solid medium: sheep blood agar 5\% (Himedia ${ }^{\circledR}$, Bhaveshwar, Mumbai, India), with a pH of 7.0 - 7.2, in glass Petri dishes; and liquid medium: brain heart infusion - BHI (Himedia ${ }^{\circledR}$, Bhaveshwar, Mumbai, India) in test tubes $(10 \mathrm{~mL})$ with a screw cap, identified with permanent marker. Abscesses were longitudinally cut using sterile scalpel blades (No. 24), within the confines of a fume hood and with the protection of a Bunsen burner. An inoculation loop was used to seed the caseous content in blood agar as primary culture, which was incubated at 37 ${ }^{\circ} \mathrm{C}$ (Fanem ${ }^{\circledR} 502$ incubator) and read after 24 and 72 hours. Subsequently, the microorganisms were replicated in BHI for biochemical identification.

The isolated microorganisms underwent a catalase test using a 3\% hydrogen peroxide solution and bacterioscopic examinations using the Gram method $\left(\right.$ Laborclin $\left.^{\circledR}\right)$. Slides were read under a 5-head B-500 Ti-5 (Optika ${ }^{\circledR}$ ) optical microscope using an 100X objective lens at the Laboratory of Animal Pathology (LPA) of the Veterinary Hospital of the Federal University of Campina Grande, Patos Campus, PB. C. pseudotuberculosis was identified based on the Manual of Clinical Microbiology (MURRAY et al., 1999). The diagnostic test results and characterization charts were stored in a database (Microsoft Excel ${ }^{\circledR}$ 2016).

Risk variables associated with positive results were calculated using univariate analysis. Each independent variable (skin lesion, sex, and mucosal staining) was crossed with a dependent one. Variables that presented a $p$ value of $\leq 0.05$, using the chi-square test (ZAR, 1999), were selected to determine the Odds ratio (THRUSFIELD, 2007). The SPSS 20.0 software was used for all analyses.

\section{Results}

CL-like lesions were found in 25.33\% (77/304) of the animals. Bacteriological examinations confirmed C. pseudotuberculosis in $84.42 \%(65 / 77)$, which represents $21.38 \%(65 / 304)$ of the animals evaluated (Table 1).

Table 1. Evaluation of abscesses for caseous lymphadenitis using microbiological isolation, catalase tests, and Gram staining.

\begin{tabular}{lcc}
\hline \multicolumn{1}{c}{ Result } & Number of animals & Total (\%) \\
\hline (+) Corynebacterium pseudotuberculosis & 65 & $(84.42)$ \\
Other microorganisms & 8 & $(10.38)$ \\
Absence of growth & 4 & $(5.20)$ \\
\hline Total & $\mathbf{7 7}$ & $\mathbf{( 1 0 0 )}$ \\
\hline
\end{tabular}

A prevalence of $13.16 \%$ (40/304) in females and $8.22 \%(25 / 304)$ in males was noted. The clinical form was observed in $11.51 \%$ (35/304), of which $62.86 \%(22 / 35)$ were females and $37.14 \%$ (13/35) males. The subclinical form affected $9.87 \%$ (30/304), of which $60 \%$ (18/30) were females and
$40 \%(12 / 30)$ males. Considering the age groups, there was higher incidence in animals over 48 months of age $(40 \%)$, followed by less than 12 months (29.23\%), 12-24 (13.85\%), 24-36 (9.23\%), and 36-48 (7.69\%) months (Table 2). 


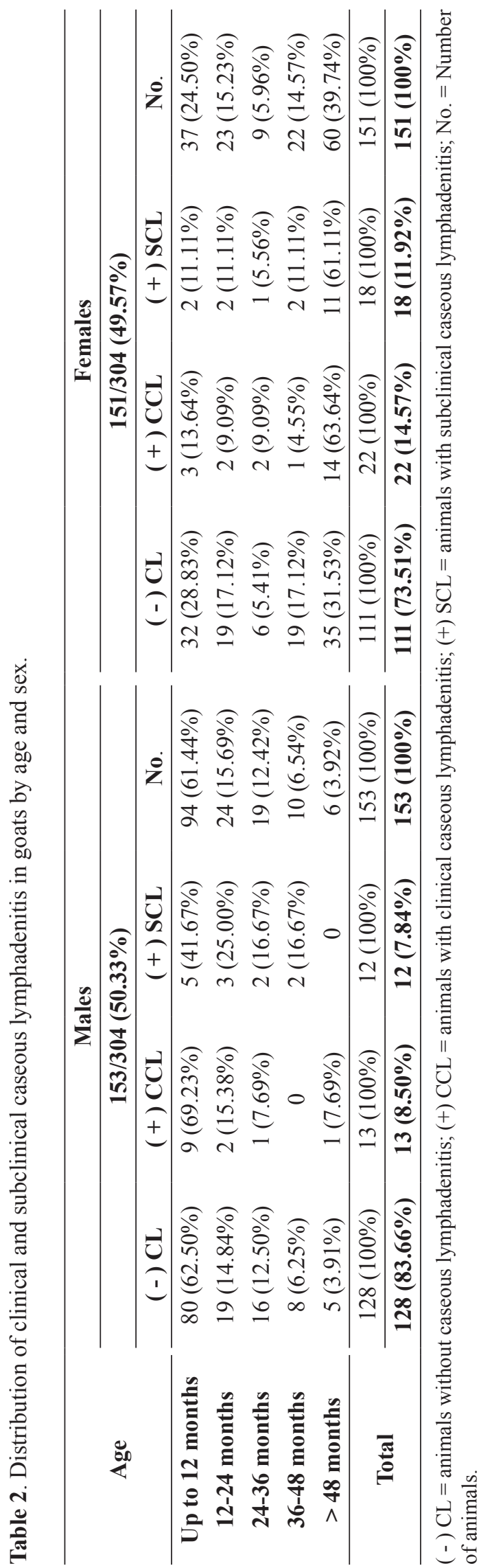


Of the positive females and males, $62.50 \%$ $(25 / 40)$ and $48 \%(12 / 25)$ had some type of skin lesion/scar, respectively. In total, $56.92 \%(37 / 65)$ of the animals had skin lesions (Table 3).

The identification method used by the owners highlighted $86.49 \%$ (32/37) of the scars (Australian marking, usually in the ear, $70.27 \%$, or in the face/masseter, $16.22 \%$ ). Scars caused by fistula were seen in $13.51 \%(5 / 37)$ of the animals, $5.41 \%$ $(2 / 5)$ in the precrural lymph nodes, and $8.10 \%$ in the prescapular, parotid, and both the parotid and precrural lymph nodes combined (Table 4).

The most affected lymph nodes were: $25.71 \%$ precrural, $11.43 \%$ mammary, and $11.43 \%$ prescapular, with extra-lymph-node abscesses in $22.86 \%$ (Table 5). Four animals (1.32\%) had concomitant clinical CL and internal lesions: one had retropharyngeal lymph node hypertrophy and caseous lesion in the lungs; one had submandibular lymph node hypertrophy and liver granuloma; one had lesions in the thoracic/ribcage region and lungs; and finally, one animal has caseous material in the flank and lungs.

As for the subclinical disease, the most affected organs were the liver (63.33\%) and lungs (13.33\%), followed by the mediastinal lymph node $(10 \%)$. Three goats had caseous lesions in more than one organ: two in the liver and lungs (6.67\%) and one in the liver and spleen (3.33\%). One animal presented an abscess in the spleen (3.33\%) (Table 6).
The multivariate analysis $(p \leq 0.05)$ showed a correlation between the presence of skin lesions/scars $($ Odds ratio $=2.394,95 \% \mathrm{CI}=1.371-4.182, p=$ $0.003)$ and $\operatorname{sex}($ Odds ratio $=1.845,95 \% \mathrm{CI}=1.053$ $3.232, p=0.044$ ) in positive females (Table 7).

\section{Discussion}

The data found in this study suggest a high frequencyoflesions caused by C.pseudotuberculosis, which is responsible for economic losses due to decreased production and high treatment costs. In addition, carcass and viscera condemnation should be considered, as described by Souza et al. (2011).

The prevalence of CL in goats sent to slaughter was $21.38 \%(65 / 304)$ (Table 1), similar to the $22.5 \%$ reported by Souza et al. (2011) under similar conditions. Andrade et al. (2012) reported a clinical prevalence of $7.7 \%$ (field), subclinical cases were excluded due to microbiological diagnosis limitations, as explained by Oreiby (2015). Inspection and palpation are techniques that do not detect all cases. In field conditions, disease control is impaired due to an inability to detect subclinical cases that maintain and disseminate C. pseudotuberculosis without having an impact (ALVES et al., 2007; SOUZA et al., 2011). A serological test (ELISA) would probably result in a higher CL prevalence in the herds analyzed by Andrade et al. (2012).

Table 3. Distribution of skin lesions in goats by age and sex.

\begin{tabular}{|c|c|c|c|c|c|c|}
\hline \multirow{3}{*}{ Age } & \multicolumn{3}{|c|}{ Males } & \multicolumn{3}{|c|}{ Females } \\
\hline & \multicolumn{3}{|c|}{$25 / 65(38.46 \%)$} & \multicolumn{3}{|c|}{$40 / 65(61.54 \%)$} \\
\hline & Without & With & No. & Without & With & No. \\
\hline Up to 12 months & $6(42.86 \%)$ & $8(57.14 \%)$ & $14(56.00 \%)$ & $2(40.00 \%)$ & $3(60.00 \%)$ & $5(12.50 \%)$ \\
\hline 12-24 months & $3(60.00 \%)$ & $2(40.00 \%)$ & $5(20.00 \%)$ & $1(25.00 \%)$ & $3(75.00 \%)$ & $4(10.00 \%)$ \\
\hline 24-36 months & $2(66.67 \%)$ & $1(33.33 \%)$ & $3(12.00 \%)$ & $2(66.67 \%)$ & $1(33.33 \%)$ & $3(7.50 \%)$ \\
\hline 36-48 months & $2(100 \%)$ & - & $2(8.00 \%)$ & $1(33.33 \%)$ & $2(66.67 \%)$ & $3(7.50 \%)$ \\
\hline$>48$ months & - & $1(100 \%)$ & $1(4.00 \%)$ & $9(36.00 \%)$ & $16(64.00 \%)$ & $25(62.50 \%)$ \\
\hline Total & $13(52.00 \%)$ & $12(48.00 \%)$ & $25(100 \%)$ & $15(37.50 \%)$ & $25(62.50 \%)$ & $40(100 \%)$ \\
\hline
\end{tabular}

Without $=$ animals with no skin lesions; With $=$ animals with skin lesions; No. $=$ Number of animals. 
Table 4. Location and types of skin lesions in goats.

\begin{tabular}{|c|c|c|c|c|c|}
\hline \multicolumn{2}{|c|}{ Type of scar } & \multicolumn{2}{|c|}{ Sex } & \multirow[t]{2}{*}{ No. } & \multirow[t]{2}{*}{$(\%)$} \\
\hline \multirow{2}{*}{\multicolumn{6}{|c|}{$\begin{array}{l}\text { Identification mark } \\
\text { Ear }\end{array}$}} \\
\hline & & & & & \\
\hline & Cut scar & $14 \mathrm{~F}$ & $5 \mathrm{M}$ & 19 & 51.35 \\
\hline & Earring & $5 \mathrm{~F}$ & $2 \mathrm{M}$ & 7 & 18.92 \\
\hline & & $19 \mathrm{~F}$ & $7 \mathrm{M}$ & 26 & 70.27 \\
\hline & Face/Masseter & $1 \mathrm{~F}$ & $5 \mathrm{M}$ & 6 & 16.22 \\
\hline & & $20 \mathrm{~F}$ & $12 \mathrm{M}$ & 32 & 86.49 \\
\hline \multicolumn{6}{|c|}{ Fistulated lymph node } \\
\hline & Precrural & $2 \mathrm{~F}$ & - & 2 & 5.41 \\
\hline & Prescapular & $1 \mathrm{~F}$ & - & 1 & 2.70 \\
\hline & Parotid & $1 \mathrm{~F}$ & - & 1 & 2.70 \\
\hline & Parotid and precrural & $1 \mathrm{~F}$ & & 1 & 2.70 \\
\hline & & $5 \mathbf{F}$ & - & 5 & 13.51 \\
\hline Total & & $25 \mathrm{~F}$ & $12 M$ & 37 & 100 \\
\hline
\end{tabular}

$\mathrm{F}=$ female $\mathrm{M}=$ male; No. $=$ number of animals.

Table 5. Distribution of external caseous lymphadenitis lesions in goats.

\begin{tabular}{lcc}
\hline \multicolumn{1}{c}{ Most affected lymph nodes } & No. & (\%) \\
\hline Precrural & 9 & 25.71 \\
Mammary & 4 & 11.43 \\
Prescapular & 4 & 11.43 \\
Parotid & 3 & 8.57 \\
Submandibular & 2 & 5.71 \\
Axillary & 2 & 5.71 \\
Retropharyngeal & 1 & 2.86 \\
Parotid and precrural & 1 & 2.86 \\
Submandibular and prescapular & 1 & 2.86 \\
& $\mathbf{2 7}$ & $\mathbf{7 7 . 1 4}$
\end{tabular}

\section{Extra-lymph-node abscesses}

Neck abscess 3

Chest wall abscess

8.57

Abscess near the scapular region

2.86

Flank abscess

2.86

\begin{tabular}{lcc}
\cline { 2 - 3 } & 8 & 22.86 \\
\hline Total & 35 & 100
\end{tabular}

No. $=$ number of animals. 
Table 6. Distribution of internal caseous lymphadenitis lesions in goats.

\begin{tabular}{lcc}
\hline \multicolumn{1}{c}{ Internal abscesses } & No. & (\%) \\
\hline Liver & 19 & 63.33 \\
Lungs & 4 & 13.33 \\
Mediastinal lymph node & 3 & 10.00 \\
Liver and lungs & 2 & 6.67 \\
Liver and spleen & 1 & 3.33 \\
Spleen & 1 & 3.33 \\
\hline Total & $\mathbf{3 0}$ & $\mathbf{1 0 0}$ \\
\hline
\end{tabular}

No. $=$ number of animals.

Table 7. Multivariate analysis results with variables $(p \leq 0.05)$ associated to caseous lymphadenitis positive goats.

\begin{tabular}{ccccc}
\hline Variables & Category & No. of positive animals (\%) & OR (95\% CI) & $\boldsymbol{p}$ \\
\hline Skin lesion & With & $37(30.30)$ & $2.394(1.371-4.182)$ & 0.003 \\
& Without & $28(15.40)$ & 1 & \\
Sex & F & $40(26.50)$ & $1.845(1.053-3.232)$ & 0.044 \\
& M & $25(16.30)$ & 1 & \\
$\begin{array}{c}\text { Preputial/vaginal } \\
\text { mucosa }\end{array}$ & F & $9(28.10)$ & $1.509(0.662-3.443)$ & 0.450 \\
M & $56(20.60)$ & $1.098(0.425-2.804)$ & 1.000 \\
Oral mucosa & $\mathrm{M}$ & $59(21.50)$ & 1 & 1.000 \\
\hline
\end{tabular}

Mucosa $=$ color; No. $=$ number of animals; $O R=$ Odds ratio $; \mathrm{CI}=$ confidence interval.

Animals aged more than 48 and less than 12 months were the most affected $(40 \%$ and $29.23 \%$, respectively), possibly because the members of these groups were more frequently sent for slaughter (Table 2). Another explanation is the fact that does remain for longer at a farm for reproduction and milk production (older than 48 months), increasing the probability of contact with the agent and becoming a source of reinfection for the herd. This is different from males, which are sent for slaughter at a young age to comply with market requirements (in most cases this is younger than 12 months, when the meat is most appreciated and free of the characteristic odor). According to Riet-Correa et al. (2013), the fact that producers do not separate goats by sex and age allows contact between the young and sick adult animals, which may be the cause of the considerable number of positive young goats in this research.

Positive adults can also be explained by disease chronicity, in which the response time to $C$. pseudotuberculosis infection may be influenced by other factors, such as the infection level and host immune competence (NASSAR, 2009), that more frequently affect animals that are older than 
one year. Subclinical animals may be a possible source of infection, maintaining the pathogen in the farm and among herds when bucks are borrowed/ purchased.

In Northeast Brazil, goat farmers sell and exchange animals in farmer's markets, breeding them without proper sanitary control. These practices may be responsible for pathogen transmission. The lack of surveillance in transportation and commercialization allows sick animals to be introduced into herds (ALVES et al., 2007; TEIXEIRA et al., 2015).

The semi-intensive breeding system (GUILHERME et al., 2017; TEIXEIRA et al., 2015 ) is the most common in the region due to long drought periods and may have contributed to greater levels of contact and proximity between infected and susceptible species. Protein and/or energy supplementation forces goats to be closer to one another to share food and water, supplied in troughs, which may be contaminated by purulent lymph node/fistulated abscess content. Additionally, there is a less frequent possibility of contracting the disease by aerosol inhalation, increasing $\mathrm{CL}$ morbidity.

In contrast to Teixeira et al. (2015), who barely used marks/identification (earring, necklace, or branding), in this study, 56.92\% (37) of the 65 positive animals had some type of skin lesion (Table 3), of which $86.49 \%$ (32) had a marking scar. This demonstrates that this type of lesion can be a gateway for microorganisms. Lymph node rupture was also seen in $13.51 \%$ (5) (Table 4), which was the main form of environmental contamination (FACCIOLI-MARTINS et al., 2014).

Baird and Malone (2010) reported the lymph nodes of the head and neck to be the most affected in a study in the United Kingdom, which differs from this study. This corroborates the findings of Rizzo et al. (2017) and Souza et al. (2014), who reported that the trunk and posterior regions had greater numbers of infarcted lymph nodes. A considerable percentage of extra-lymph-node superficial abscesses (22.86\% (8/35), Table 5) and subclinical cases with liver involvement (63.33\% (19/30), Table 6) corroborate the hematogenous pathway reported by Silva Junior et al. (2013), when they isolated $C$. pseudotuberculosis from a brain abscess in goats.

Although pulmonary granulomas have a lower transmission coefficient compared to the suppuration of superficial abscesses, they may be important for maintaining the disease as a possible source of air contamination. There are two forms of organ contamination, aerogenic and hematogenous (FONTAINE; BAIRD, 2008). The high rate of lung injury suggests possible air contamination, however, lesions in other organs, such as the liver and spleen, may be caused by hematogenous contamination. According to Oreiby (2015), visceral lesions are not clinically detectable, but cause signs that depend upon the organ involved (weight loss, respiratory disorders, and chronic ruminal bloating are the most frequent).

According to Alves et al. (2007), skin lesions have a great importance in CL epidemiology. This study corroborates this information, as it verified that goats with skin lesions were 2.394 times more likely to have the disease when compared to goats without skin lesions (Table 7), proving that the skin is a probable gateway for the agent. This study also shows that females were 1.845 times more likely to be affected, corroborating the results by Souza et al. (2011), who reported a prevalence of $17.9 \%$ in females, as opposed to $13.8 \%$ in males.

\section{Conclusion}

C. pseudotuberculosis infection is present in goats sent to the Patos Municipal Slaughterhouse, Paraíba, Brazil. Younger males were more affected than females. It is important to highlight that the type of identification used can influence disease dissemination and farmers should choose methods that preserve skin integrity. Control measures, 
such as raising goat farmers' awareness, herd immunization, separation by sex and age, and correct management of sick animals, along with greater attention to sanitary inspection at slaughterhouses are suggested.

\section{Acknowledgments}

We thank the Coordination for the Improvement of Higher Education Personnel for the postgraduate grant; the Research Group on Communicable Diseases of the Federal University of Campina Grande for their efforts; and the Animal Health Research Group of Embrapa Goats and Sheep/CNPC - Sobral/CE for the opportunity and cooperation.

\section{References}

ALVES, F. S. F.; SANTIAGO, L. B.; PINHEIRO, R. R. Linfadenite Caseosa: o estado da arte. Sobral: EMBRAPA Caprinos e Ovinos, 2007. 57 p. (Documentos, 74).

ANDRADE, J. S. L.; AZEVEDO, S. S.; TELE, J. A. A.; HIGINO, S. S. S.; AZEVEDO, E. O. Ocorrência e fatores associados à infecção por Corynebacterium pseudotuberculosis em caprinos e ovinos do semiárido paraibano. Pesquisa Veterinária Brasileira, Seropédica, v. 32, n. 2, p. $116-120$, 2012. DOI: 10.1590/S0100736X2012000200004

BAIRD, G. J.; MALONE, F. E. Control of caseous lymphadenitis in six sheep flocks using clinical examination and regular ELISA testing. Veterinary Record, London, v. 166, p. 358-362, 2010. DOI: 10.1136/ vr.b4806

FACCIOLI-MARTINS, P. Y.; ALVES, F. S. F.; PINHEIRO, R. R. Linfadenite Caseosa: perspectivas no diagnóstico, tratamento e controle. Sobral: EMBRAPA Caprinos e Ovinos, 2014, 71 p. (Documentos, 113).

FARIAS, J. L. S.; ARAÚJO, M. R. A.; LIMA, A. R.; ALVES, F. S. F.; OLIVEIRA, L. S.; SOUZA, H. A. Análise socioeconômica de produtores familiares de caprinos e ovinos no semiárido cearense, Brasil. Archivos de Zootecnia, Córdoba, v. 241, n. 63, p. 13-24, 2014. DOI: 10.4321/S0004-05922014000100002

FONTAINE, M. C. A.; BAIRD, G. J. Caseous lymphadenitis. Small Ruminant Research, Amsterdam, v. 76 , n. $1-2$, p. $42-48,2008$. DOI: $10.1016 / j$. smallrumres.2007.12.025
FRANDSON, R. W.; LEE WILKE, W.; FAILS, A. D. Anatomia do sistema digestório. In: FRANDSON, R. W.; LEE WILKE, W.; FAILS, A. D. Anatomia e fisiologia dos animais de fazenda. 7. ed. Rio de Janeiro: Guanabara Koogan, p. 269-288, 2011.

GUILHERME, R. F.; FARIAS, D. A.; ALVES, J. R. A.; COSTA, D. F.; PINHEIRO, R. R.; ALVES, F. S. F.; AZEVEDO, S. S.; ALVES, C. J. Caracterização dos sistemas de produção de ovinos e caprinos no estado da Paraíba, Semiárido do Nordeste, Brasil. Semina: Ciências Agrárias, Londrina, v. 38, n. 4, p. 2163-2178, 2017. DOI: $10.5433 / 1679-0359.2017 v 38 n 4 p 2163$

INSTITUTO BRASILEIRO DE GEOGRAFIA E ESTATÍSTICA-IBGE. Pesquisa pecuária municipal. Rio deJaneiro:IBGE,2018.Disponívelem:https://censos.ibge. gov.br/agro/2017/templates/censo_agro/ resultadosagro/ pecuaria.html localidade $=0 \&$ tema $=7566$. Acesso em: 9 ago. 2018.

MURRAY, P. R.; BARON, E. J.; PFALLER, M. A.; TENOVER, F. C.; YOLKEN, R. H. Manual of Clinical Microbiology. 7. ed. Washington: American Society for Microbiology, 1999. 846 p.

NASSAR, A. F. C. Linfadenite caseosa ou "mal do caroço”. São Paulo: Instituto Biológico, 2009. Disponível em: http://www.biologico.agricultura.sp.gov.br/artigos ok.php?id_artigo=101. Acesso em 02 jan. 2018.

OREIBY, A. F. Diagnosis of caseous lymphadenitis in sheep and goat. Small Ruminant Research, Amsterdã, v. 123 , n. 1, p. $160-166,2015$. DOI: 10.1016/j. smallrumres.2014.11.013

PACHECO, L. G. C.; PENA, R. R.; CASTRO, T. L. P.; DORELLA, F. A.; BAHIA, R. C.; CARMINATI, R.; FROTA, M. N. L.; OLIVEIRA, S. R.; MEYER, R.; ALVES, F. S. F.; MIYOSHI, A.; AZEVEDO, V. Multiplex PCR assay for identification of Corynebacterium pseudotuberculosis from pure cultures and for rapid detection of this pathogen in clinical samples. Journal of Medical Microbiology, Reading, v. 56, n. 4, p. 480-486, 2007. DOI: $10.1099 /$ jmm.0.46997-0

PEREIRA, H. M.; SOARES, D. M.; ROCHA, T. B.; MARQUES, C. H. M. F.; ALVES, J. S.; SILVA, A. T. L. Linfadenite clínica em rebanhos ovinos e caprinos no município de Chapadinha/MA. Revista Acadêmica Ciência Animal, Curitiba, v. 15, p. 57-58, 2017. DOI: 10.7213/cienciaanimal.v15iSuppl\%202.16899

RIET-CORREA, B.; SIMÕES, S. V. D.; FILHO, J. M. P.; AZEVEDO, S. S.; MELO, D. B.; BATISTA, J. A.; NETO, E. G. M.; RIET-CORREA, F. Sistemas produtivos de caprinocultura leiteira no semiárido paraibano: caracterização, principais limitantes e avaliação de 
estratégias de intervenção. Pesquisa Veterinária Brasileira, Seropédica, v. 33, n. 3, p. 345-352, 2013. DOI: $10.1590 / \mathrm{S} 0100-736 \mathrm{X} 2013000300012$

RIZZO, H.; CARVALHO, J. S.; JÚNIOR, N. S. S.; JESUS, T. K. S.; JÚNIOR, C. M. M. T.; REIS, D. D.; ALMEIDA, F. F.; MAGALHÃES, M. V. F.; FARIAS, C. E.; COELHO, T. R. S. Avaliação clínica de linfonodos superficiais de pequenos ruminante criados no estado de Sergipe, Brasil. Medicina Veterinária (UFRPE), Recife, v. 11, n. 1, p. 18-28, 2017. DOI: 10.26605/ medvet-n1-1595

RODRIGUES, B. R.; COELHO, M. C. S. C.; COELHO, M. I. S. Aspectos sanitários e de manejo em criações de caprinos leiteiros produzidos na comunidade de Caroá, distrito de Rajada, Petrolina - PE. Revista Brasileira de Agropecuária Sustentável, Viçosa, v. 6, n. 2, p. 9-18, 2016. DOI: $10.21206 /$ rbas.v6i2.324

SILVA JUNIOR, A. B.; DESTRO, C. R.; PAGLIOSA, G. M.; VIOTT, A. M.; GIRALDES, F. F.; TOSTES, R. A. Abscesso cerebral por Corynebacterium pseudotuberculosis em um caprino. Archives of Veterinary Science, Curitiba, v. 18, n. 3, p. 1-11, 2013. Supplement 2. DOI: 10.5380/avs.v18i3

SOUZA, A. M. S.; JÚNIOR, E. M. D.; ZAFALON, L. F.; VESCHI, J. L. A. Ocorrência de cicatrizes e abscessos causados pela linfadenite caseosa em caprinos do rebanho da Embrapa Semiárido. IN: JORNADA DE INICIAÇÃO CIENTÍFICA DA EMBRAPA SEMIÁRIDO, 9., 2014, Petrolina. Anais... Petrolina: EMBRAPA Semiárido, 2014. p. 325-330. Disponível em: https://www.embrapa. br/busca-de-publicacoes/-/publicacao/1013685/ ocorrencia-de-cicatrizes-e-abscessos-causados-pelalinfadenitecaseosaem caprinos-do-rebanho-da-embrapasemiarido. Acesso em: 9 jan. 2018.
SOUZA, M. F.; CARVALHO, A. Q.; GARINO, F. J.; RIET-CORREA, F. Linfadenite caseosa em ovinos deslanados abatidos em um frigorífico da Paraíba. Pesquisa Veterinária Brasileira, Seropédica, v. 31, n. 3, p. 224-230, 2011. DOI: /10.1590/S0100736X2011000300007

TEIXEIRA, W. C.; SANTOS, H. P.; SILVA, J. C. R.; RIZZO, H.; MARVULO, M. F. V.; CASTRO, R. S. Perfil zoosanitário dos rebanhos caprinos e ovinos em três mesorregiões do estado do Maranhão, Brasil. Acta Veterinaria Brasilica, Mossoró, v. 9, n. 1, p. 34-42, 2015. DOI: $10.21708 / a v b .2015 .9 .1 .4438$

THRUSFIELD, M. Veterinary epidemiology. $3^{\text {th }}$ ed. Oxford: Blackwell Science, 2007. 624 p.

VESCHI, J. L. A. Manejo sanitário de doenças infecciosas. In: VOLTOLINI, T. V. (Ed.). Produção de caprinos e ovinos no semiárido. Petrolina: EMBRAPA Semiárido, 2011. p. 323-354.

VESCHI, J. L. A.; RAMOS, E. M.; ZAFALON, L. F. Linfadenite caseosa: sinais clínicos, localização dos principais linfonodos acometidos, recomendações para prevenção e controle. Petrolina: EMBRAPA Semiárido, 2015. 2 p. (Instruções Técnicas, 123).

WINDSOR, P. A. Managing control programs for ovine caseous lymphadenitis and paratuberculosis in Australia and the need for persistent vaccination. Veterinary Medicine: Research and Reports, London, v. 5, p. 1-12, 2014. DOI: $10.2147 /$ VMRR.S44814

WINDSOR, P. A.; BUSH, R. D. Caseous lymphadenitis: Present and near forgotten from persistent vaccination? Small Ruminant Research, Amsterdã, v. 142, p. 6-10, 2016. DOI: 10.1016/j.smallrumres.2016.03.023

ZAR, J. H. Biostatistical analysis. $4^{\text {th }}$ ed. Upper Saddle River: Prentice Hall, 1999. 663 p. 
